\title{
Bacterial endocarditis of mitral valve in Marfan syndrome
}

\author{
Vijay R. Soman, Gerald Breton, Melvin Hershkowitz, and Herbert Mark \\ From the Departments of Medicine and Pathology, fersey City Medical Center, fersey City, N.f., and The \\ New fersey Medical School, Newark, N.F., U.S.A.
}

An unusual case of bacterial endocarditis in Marfan syndrome is reported. A review of the published reports revealed $2 I$ previously reported cases. The aortic valve, though commonly abnormal in Marfan syndrome, was rarely involved by the endocarditis. In contrast, the mitral valve was the favoured site of infection in these patients. Our own patient had staphylococcal endocarditis of both the aortic and mitral valves, the only such combination of infecting organism and sites in the published reports to date. The low incidence of aortic valve involvement remains unexplained. There is extreme mortality in Marfan patients affected by endocarditis, and, it seems, only one documented cure in the entire published reports.

The Marfan syndrome, a heritable disorder of connective tissue (Marfan, 1896), is characterized by variable abnormalities of skeletal, ocular, and cardiovascular systems. Cardiovascular involvement is important because of its prognostic significance (Murdoch et al., 1972). The most commonly recognized cardiovascular defects are aortic dilatation and its complications, aortic regurgitation and dissecting aneurysm.

Deformity of the mitral valve in a patient with Marfan syndrome was first described by Salle (I912). Subsequently, others (Traisman and Johnson, 1954; McKusick, 1966) emphasized that mitral valve abnormalities may occur in patients with this syndrome. Few cases of bacterial endocarditis in Marfan syndrome have been reported, despite the known susceptibility of diseased valves to such infection (Hiejima et al., 1968). Furthermore, it is curious that when bacterial endocarditis occurs it almost always involves the relatively uncommon mitral abnormalities rather than the more common lesions of the aortic valve (Di Matteo et al., r97I; McKusick, I972).

In this report we describe our experience with a patient who had typical Marfan syndrome and died of acute staphylococcal endocarditis involving both the aortic and mitral valves.

\section{Case report}

A r4-year-old white boy was admitted to the Jersey City Medical Center on 8 August I97 I in a semiconscious state. The day before admission he had fever, severe headache, two episodes of projectile vomiting, and gradually became drowsy. There was no history of convulsions, head injury, ear discharge, recent dental treatment, or narcotics use. A month before admission, the patient had an upper respiratory infection, for which he received symptomatic treatment.

Six years previously he was treated in another hospital for pneumonia, and was told that he had a heart murmur, but no diagnostic procedures were performed. There were no other major illnesses or operations.

\section{Family history}

The patient's mother was alive and well. His father had Marfan syndrome, and died suddenly at home in 1971, after having severe chest pain for several hours. No necropsy was performed. The patient had 3 brothers and 2 sisters. All but one (a sister) were said to have Marfan syndrome.

\section{Physical examination}

On admission the patient was stuporous, restless, and dehydrated. His temperature was $40.5^{\circ} \mathrm{C}$, pulse 148 a minute and regular respirations 40 a minute, and blood pressure $130 / 60 \mathrm{mmHg}$. His height was $184 \mathrm{~cm}$ and his span was $207 \mathrm{~cm}$. Extreme arachnodactyly was present. There were no skull deformities. He had a high arched palate. A pectus carinatum deformity was present on an elongated chest. The pupils were normal, reacted well to light, and showed no quivering of the irises. Slit-lamp examination was not done. The fundi were normal. There was slight neck stiffness. The deep tendon reflexes were depressed throughout, and the Babinski sign was elicited on the left. There were no other abnormal reflexes, sensory deficits, or motor weaknesses. Examination of the heart showed sinus tachycardia. The apex 
beat was in the fifth intercostal space in the midclavicular line, with sounds of normal quality. There was a pansystolic grade $3 / 6$ murmur, best heard at the apex, conducted towards the left axilla. No other murmurs were heard. All peripheral pulses were easily felt. The lungs were clear and the abdomen normal. There was no hepatosplenomegaly.

\section{Laboratory investigations}

White cell count $13,000 / \mathrm{mm}^{3}$, 74 per cent segmented neutrophils, is per cent stab forms, Io per cent lymphocytes, I per cent monocytes. Haematocrit, haemoglobin, serum electrolytes, and blood urea nitrogen normal. Lumbar puncture: initial pressure $250 \mathrm{~mm}$ $\left(\mathrm{H}_{2} \mathrm{O}\right)$, final pressure $170 \mathrm{~mm}$; protein $10 \mathrm{mg} / 100 \mathrm{ml}$, sugar I Io mg/roo ml, cell count $60 / \mathrm{mm}^{3}$ with 90 per cent polymorphonuclears. Urinalysis: specific gravity $\mathrm{I} \cdot 02 \mathrm{I}$, 4+ albumin, many red blood cells and epithelial casts, few white cells. Five blood cultures, reported after death: pure cultures of coagulase positive Staphylococcus aureus. Chest $x$-ray showed moderate dilatation of ascending aorta, clear lung fields, normal cardiac contour. Electrocardiogram was suggestive of left ventricular and right atrial enlargement.

\section{Hospital course}

A provisional diagnosis of Marfan syndrome with meningitis was made, and treatment was started with intravenous ampicillin (multiple blood cultures were drawn). However, four hours after admission, he lapsed into coma, and died 32 hours later.

\section{Necropsy}

The pertinent postmortem findings were in the heart, brain, liver, kidneys, and pituitary, and adrenal glands. The heart was enlarged and weighed $370 \mathrm{~g}$. The left

TABLE Reported cases of Marfan syndrome with bacterial endocarditis

\begin{tabular}{|c|c|c|c|c|c|}
\hline Reference & $\begin{array}{l}\text { Evidence of bacterial } \\
\text { endocarditis }\end{array}$ & Organism & Valve affected & $\begin{array}{l}\text { Operation } \\
\text { and/or } \\
\text { necropsy }\end{array}$ & Comments \\
\hline $\begin{array}{l}\text { I) Olcott (r940) } \\
\text { 2) Vivas-Salas and } \\
\text { Sanson (I948) }\end{array}$ & $\begin{array}{l}\text { Heart blood culture } \\
\text { Histological exam- } \\
\text { ination of mitral } \\
\text { valve }\end{array}$ & $\begin{array}{l}\text { Esch. coli } \\
\text { Gram-positive } \\
\text { cocci }\end{array}$ & $\begin{array}{l}\text { Mitral } \\
\text { Mitral }\end{array}$ & $\begin{array}{l}\text { Yes } \\
\text { Yes }\end{array}$ & \\
\hline $\begin{array}{l}\text { 4) McKusick (I955) } \\
\text { 5) Tolbert and } \\
\text { Birchall (I956) }\end{array}$ & $\begin{array}{l}\text { Blood culture } \\
\text { Blood culture }\end{array}$ & $\begin{array}{l}\text { Strep. viridans } \\
\text { Haemolytic } \\
\text { streptococci }\end{array}$ & $\begin{array}{l}\text { Mitral } \\
\text { Mitral, ventricular } \\
\text { septal defect, } \\
\text { persistent ductus } \\
\text { arteriosus }\end{array}$ & $\begin{array}{l}\text { Yes } \\
\text { Yes }\end{array}$ & Positive family history \\
\hline $\begin{array}{l}\text { 7) Hirosawa et al. } \\
\text { (I957) }\end{array}$ & Blood culture & Strep. viridans & $\begin{array}{l}\text { Ventricular septal } \\
\text { defect }\end{array}$ & No & \\
\hline $\begin{array}{l}\text { 8) Miller and } \\
\text { Pearson (I959) }\end{array}$ & $\begin{array}{l}\text { Mitral valve showed } \\
\text { vegetations }\end{array}$ & Unknown & Mitral & Yes & $\begin{array}{l}\text { History of acute } \\
\text { rheumatic fever at } \\
\text { age ro years }\end{array}$ \\
\hline $\begin{array}{l}\text { 9) Sinclair, Kitchen, } \\
\text { and Turner } \\
\text { (1960) (Case I5) }\end{array}$ & $\begin{array}{l}\text { Past history of sub- } \\
\text { acute bacterial } \\
\text { endocarditis treated } \\
\text { successfully }\end{array}$ & Unknown & $\begin{array}{l}\text { Unknown (basal } \\
\text { systolic murmur) }\end{array}$ & No & \\
\hline $\begin{array}{l}\text { I0) Bowers and Lim } \\
\text { (I962) }\end{array}$ & Blood culture & Strep. viridans & $\begin{array}{l}\text { Eisenmenger's } \\
\text { complex }\end{array}$ & No & $\begin{array}{l}\text { Phenotypically Marfan } \\
\text { syndrome with } \\
\text { intracranial calcifica- } \\
\text { tion and history of } \\
\text { maternal rubella; } \\
\text { probably first docu- } \\
\text { mented cure of sub- } \\
\text { acute bacterial } \\
\text { endocarditis }\end{array}$ \\
\hline $\begin{array}{l}\text { II) Wunsch et al. } \\
\text { (I965) }\end{array}$ & Blood culture & Strep. viridans & Mitral & Yes & $\begin{array}{l}\text { Patient's father prob- } \\
\text { ably had Marfan } \\
\text { syndrome }\end{array}$ \\
\hline
\end{tabular}


TABLE (Cont'd)

\begin{tabular}{|c|c|c|c|c|c|}
\hline Reference & $\begin{array}{l}\text { Evidence of bacterial } \\
\text { endocarditis }\end{array}$ & Organism & Valve affected & $\begin{array}{l}\text { Operation } \\
\text { and/or } \\
\text { necropsy }\end{array}$ & Comments \\
\hline 12) Maekawa (1965) & Blood culture & Strep. viridans & $\begin{array}{l}\text { Ventricular septal } \\
\text { defect }\end{array}$ & Yes & \\
\hline $\begin{array}{l}\text { 13) Read, Thal, and } \\
\text { Wendt (1965) }\end{array}$ & $\begin{array}{l}\text { History of pneumo- } \\
\text { coccal endocarditis } \\
\text { at age } 7 \text { years }\end{array}$ & Unknown & Mitral & Yes & $\begin{array}{l}\text { Normal physical } \\
\text { appearance, floppy- } \\
\text { valve syndrome }\end{array}$ \\
\hline $\begin{array}{l}\text { 14) Read et al. } \\
\text { (1965) (T.J.) }\end{array}$ & $\begin{array}{l}\text { History of strepto- } \\
\text { coccal endocarditis } \\
\text { at age } 23 \text { years }\end{array}$ & Unknown & Mitral & Yes & $\begin{array}{l}\text { Moderate hypermo- } \\
\text { bility of joints and } \\
\text { scoliosis, floppy- } \\
\text { valve syndrome }\end{array}$ \\
\hline $\begin{array}{l}\text { 15) Shiina et al. } \\
\text { (I966) }\end{array}$ & Blood culture & Strep. viridans & Mitral & Yes & \\
\hline $\begin{array}{l}\text { 16) Keech et al. } \\
\text { (1966) (T.J.Jr.) }\end{array}$ & $\begin{array}{l}\text { Clinically probable- } \\
\text { (repeated blood } \\
\text { cultures negative) }\end{array}$ & Unknown & $\begin{array}{l}\text { Unknown } \\
\text { ?pulmonary } \\
\text { ?aortic }\end{array}$ & No & $\begin{array}{l}\text { Positive family history; } \\
\text { mild pulmonary } \\
\text { stenosis; abnor- } \\
\text { mality of aortic } \\
\text { valve on angio- } \\
\text { cardiography }\end{array}$ \\
\hline 17) Iwase (1967) & Blood culture & Strep. viridans & $\begin{array}{l}\text { Ventricular septal } \\
\text { defect }\end{array}$ & No & $\begin{array}{l}\text { Positive family } \\
\text { history }\end{array}$ \\
\hline $\begin{array}{l}\text { 18) Cohen and Kaye } \\
(1967)\end{array}$ & Blood culture & Staph. aureus & Mitral & Yes & $\begin{array}{l}\text { Heroin addict; no } \\
\text { 'predisposing lesion } \\
\text { of mitral valve'; but } \\
\text { histology consistent } \\
\text { with bacterial } \\
\text { endocarditis }\end{array}$ \\
\hline $\begin{array}{l}\text { 19) Hiejima et al. } \\
\text { (rg68) (Case I) }\end{array}$ & Blood culture & Strep. viridans & Mitral & Yes & $\begin{array}{l}\text { Myopia in sibs and } \\
\text { mother }\end{array}$ \\
\hline $\begin{array}{l}\text { 20) Aslam et al. } \\
\text { (I970) }\end{array}$ & Blood culture & Aspergillus & Aortic & Yes & $\begin{array}{l}\text { Family history sug- } \\
\text { gestive of Marfan; } \\
\text { postoperative endo- } \\
\text { carditis; aortic valve } \\
\text { showed thin } \\
\text { fenestration }\end{array}$ \\
\hline $\begin{array}{l}\text { 21) Di Matteo et al. } \\
\text { (197I) }\end{array}$ & Blood culture & Strep. viridans & Mitral & Yes & $\begin{array}{l}\text { Clinically forme } \\
\text { fruste Marfan }\end{array}$ \\
\hline
\end{tabular}

ventricular wall measured $I \cdot 2 \mathrm{~cm}$ and the right ventricular wall $0.3 \mathrm{~cm}$. The aortic and mitral valvular circumferences were enlarged: $7.5 \mathrm{~cm}$ and II cm, respectively. Both valves were thickened at their free borders and showed occasional pinpoint greyish elevations. No gross lesions could be recognized in the myocardium. The ascending aorta was moderately dilated. Microscopical examination of the mitral and aortic valves showed vegetations populated by Gram-positive cocci. At the bases, remote from any exudate, there was prominent mucinous degeneration of the ground substance. This was more noticeable in the aortic valve, where there was a minute linear defect partially filled by a few red blood cells. There were numerous micro-abscesses within the myocardium, liver, kidney, brain, pituitary, and adrenal glands. (Postmortem blood culture from the heart was positive for Staphylococcus aureus, coagulase positive.)

\section{Discussion}

The first case of bacterial endocarditis in Marfan syndrome was reported by Olcott (1940). While isolated cases continue to be reported, the exact incidence of endocarditis among patients with Marfan syndrome cannot be determined (Wunsch, Steinmetz, and Fisch, I965; Iwase, I967; Di Matteo et al., I97 I). Our own survey revealed 21 adequately documented cases, the important features of which are summarized in the Table.

Of the 21 patients, the infecting organism was identified in I5. It was not demonstrated in 6 cases, but other supporting evidence for the diagnosis of bacterial endocarditis was available. Streptococci were isolated in II, of which 9 were Streptococcus viridans. A variety of organisms was isolated in 4 patients. Staphylococcus aureus, which was the offending organism in our patient, was present in only one other recorded case of endocarditis in Marfan syndrome (Cohen and Kaye, 1967).

Clinical examination pointed to the site of the 
underlying cardiac lesion in 18 patients. This location was confirmed by surgery or necropsy in 15 . Congenital malformations were present in 5. The mitral valve was involved alone II times and the aortic valve only twice. Thus, the mitral valve was the site of infection in almost two-thirds of these patients. Considering the well-known susceptibility of aortic valve lesions to bacterial infection, and the predominant involvement of the aortic valve in Marfan syndrome, this finding was unexpected. Why the aortic valve is so much less vulnerable than the mitral valve is unexplained. To our knowledge, our patient is the first showing histological evidence of bacterial endocarditis affecting both the aortic and mitral valves.

The Marfan syndrome with bacterial endocarditis has a dismal prognosis, one that is probably worse than that of patients with endocarditis complicating other forms of heart disease. We were able to find only one documented cure in the published reports. A high degree of suspicion, early diagnosis, and the prompt institution of treatment may improve the otherwise grave prognosis of these patients.

\section{References}

Aslam, P. A., Eastridge, C. E., Bernhardt, H., and Pate, J. W. (1970). Myxomatous degeneration of cardiac valves. Chest, 57,535 .

Bowers, D., and Lim, D. W. (1962). Subacute bacterial endocarditis and Marfan's syndrome. Canadian Medical Association fournal, 86, 455 .

Cohen, D. N., and Kaye, D. (1967). Staphylococcal endocarditis in narcotic addict with Marfan's syndrome. New York State Fournal of Medicine, 67, 2362.

Di Matteo, J., Vacheron, A., Sabaut, D., Delvaux, J. C., and Audoin, J. (197I). Anéurysmes multiples de la valve mitrale; endocardite bactérienne et syndrome de Marfan. Coeur et Médecine Interne, 10, 519.

Hiejima, K., Tsuchiya, S., Sakamoto, Y., and Shiina, S. (1968). Two cases of Marfan's syndrome associated respectively with subacute bacterial endocarditis and WolffParkinson-White syndrome. Fapanese Heart fournal, 9, 208.

Hirosawa, K., Kondo, M., Terauchi, T., and Suzuki, M. (1957). One case of Marfan's syndrome. Kokyu to funkan, $5,307$.

Iwase, S. (1967). One case of Marfan syndrome associated with subacute bacterial endocarditis. Nippon Ika Daigaku Zasshi, 34, 360.

Keech, M. K., Wendt, V. E., Read, R. C., Bistue, A. R., and Bianchi, F. A. (I966). Family studies of the Marfan syndrome. Fournal of Chronic Diseases, 19, 57.

Maekawa, M. (1965). Sudden death associated with chronic recurrent cardiac failure. Sogo Rinsho, 14, 344.
Marfan, A. B. (1896). Un cas de déformation congénitale des quatre membres plus prononcée aux extrémités charactérisée par l'allongement des os avec un certain degré d'amincissement. Bulletins et Mémoires de la Société Médicale des Hôpitaux de Paris, 13, 220.

McKusick, V. A. (1955). The cardiovascular aspects of Marfan's syndrome. Circulation, 11, 321.

McKusick, V. A. (1966). Heritable Disorders of Connective Tissue, 3rd ed., pp. 84-85. C. V. Mosby, St. Louis.

McKusick, V. A. (1972). Heritable Disorders of Connective Tissue, 4th ed., p. 12r. C. V. Mosby, St. Louis.

Miller, R., and Pearson, R. J., Jr. (1959). Mitral insufficiency simulating aortic stenosis. Report of an unusual manifestation of Marfan's syndrome. New England fournal of Medicine, 260, 1210.

Murdoch, J. L., Walker, B. A., Halpern, B. A., Kuzma, J. W., and McKusick, V. A. (1972). Life expectancy and causes of death in the Marfan syndrome. New England fournal of Medicine, 286, 804 .

Olcott, C. T. (1940). Arachnodactyly (Marfan's syndrome) with severe anemia. American fournal of Diseases of Children, 60, 660 .

Pappas, E. G., Mason, D., and Denton, C. (1957). Marfan's syndrome. A report of three patients with aneurysm of the aorta. American fournal of Medicine, 23, 426.

Read, R. C., Thal, A. P., and Wendt, V. E. (1965). Symptomatic valvular myxomatous transformation (the floppyvalve syndrome). Circulation, 32, 897.

Salle, V. (1912). Ueber einen Fall von angeborener abnormer Grösse der Extremitäten mit einem an Akromegalie errinernden Symptomencomplex. Fahrbuch für Kinderheilkunde, 75, 540 .

Schorr, S., Braun, K., and Wildman, J. (I95I). Congenital aneurysmal dilatation of the ascending aorta associated with arachnodactyly. American Heart fournal, 42, 6 Io.

Shiina, S., Kanetsu, K., Bizen, R., Tsuchiya, S., Ochima, M., and Mitsunaga, Y. (1966). An autopsy of Marfan case, associated with subacute bacterial endocarditis. Fournal of the fapanese Society of Internal Medicine, 54, 1341.

Sinclair, R. J. G., Kitchin, A. H., and Turner, R. W. D. (1960). The Marfan syndrome. Quarterly fournal of Medicine, 29, 19.

Tolbert, L. E., and Birchall, R. B. (1956). Marfan's syndrome with interventricular septal defect found at autopsy. Ochsner Clinical Reports, 2, 48.

Traisman, H. S., and Johnson, F. R. (1954). Arachnodactyly associated with aneurysm of the aorta. American fournal of Diseases of Children, 87, 156.

Vivas-Salas, E., and Sanson, R. E. (1948). Sindrome de Marfan, sin cardiopatia congenita y con endocarditis lenta confirmada por la autopsia. Archivos del Instituto de Cardiologia de Mexico, 18, 217.

Wunsch, C. M., Steinmetz, E. F., and Fisch, C. (1965). Marfan's syndrome and subacute bacterial endocarditis. American fournal of Cardiology, 15, 102.

Requests for reprints to Dr. Melvin Hershkowitz, Department of Medicine, Jersey City Medical Center, 50 Baldwin Avenue, Jersey City, N.J. 07304, U.S.A. 